DOI: 10.20472/IAC.2018.001.019

\title{
KULPATSORN SRIBOONPENG
}

Suan Sunandha Rajabhat University, Thailand

\section{THANASUWIT THABHIRANRAK}

Suan Sunandha Rajabhat University, Thailand

\section{FACTOR INFLUENCING A DECISION IN STUDYING IN THE MASTER OF BUSINESS ADMINISTRATION PROGRAM OF SUAN SUNANDHA RAJABHAT UNIVERSITY}

\begin{abstract}
:
This research aims to study a desire to study in the Master of Business Administration Program of Suan Sunandha Rajabhat University as well factors influencing the students' decision. The findings from this research can be beneficial for the university and other related administrators and personnel in that they can serve as valuable information in planning and developing marketing and public relation strategies for the program more effectively. The findings can also be used as information to encourage and fulfill the desire of the potential students of the Master of Business Administration Program. This research employed a quantitative research methodology. The sample consisted of 100 respondents who lived in Bangkok Metropolitan. Data were collected with the use of a questionnaire and then analyzed with descriptive statistics. The study was carried out for the period of 10 months between October 2017 and July 2018. The research findings showed that overall, the independent variables influencing the potential students' decisions to choose the program were rated the highest level. These independent variables or the factors influencing the decision included, sorted in a descending order, image of the university, fee, promotional activities, curriculums and teaching and learning activities, and location of the university. It was also found that Suan Sunandha Rajabhat University was reputable for its high standard in education among students and people therefore there were many people interested to study there.
\end{abstract}

\section{Keywords:}

Decision Making; Business Administration; Further Study

JEL Classification: Y80, L૫, Lrtic 


\section{Background and Significance of the Research}

Education is a significant process enabling people to develop the quality of their life so that they can live in the society happily. Education also plays an important role in the development of the society and country as a whole. Specifically, it helps the country be developed in such a way that it can respond appropriately to global changes.

The Office of the National Economic and Social Development Board is an organization responsible to formulate development strategies for the country in varied dimensions (i.e. social, economic, and environment). It has clearly formulated an education development plan in the Eight National Economic and Social Development Plan which sets human resource development as one of the primary goals of the country. In this plan, the development of education to meet with global standards is emphasized. Moreover, the Ninth National Economic and Social Development Plan (B.E. 20022006) also determines approaches for reforming education in the country by focusing on lifelong learning and student-centered learning. Through these new approaches, students are encouraged to apply their knowledge learnt from the classrooms in the real life so that they can have firsthand learning experiences. Besides, students are encouraged to make their own decision to study in the courses which they are good at, have appropriate capabilities and have real interest in. In addition, the new approaches of education development also focus on the development of multiple learning programs in schools and universities. The learning programs are more flexible and suitable to the context of the communities where educational institutions are located (Kittisatta Poompeng 2008)

A study at the postgraduate level is a further study from the graduate level. Students who decide to study at the postgraduate level generally aim to gain higher level of academic knowledge related to their field of undergraduate study or their current jobs. Moreover, they also would like to gain advanced concepts and practices in a certain area so that they can become experts in that field as well as to gain new and creative ideas so that they can develop new body of knowledge to develop the society.

At the present time, as the education system of Thailand has been expanded to every region and there are more universities and university campuses offering postgraduate courses in many provinces, there are higher number of students who are interested to further their study at the postgraduate level, especially at the master's degree level. Reasons and motivations of these students to study are different. For example, some students would like to gain higher level of knowledge and experiences in a certain field so that they can use them for their career development whereas some students aim to gain social networks. The motivations to study are also different depending on students' demographic background and opportunity.

As the researcher is an academic support officers in the Master of Business Administration program of Suan Sunandha Rajabhat University, Thailand, she was interested in examining factors influencing students' decision to study in this program. 
The findings gained from this study are expected to be useful pieces of information for the university and stakeholders to plan and improve the program content, its marketing and public relations strategy more efficiently. They are also expected to help encourage prospective students to study in this program and to fulfill their motivations to study appropriately.

\section{Research Objectives}

This study aims to:

1. Study motivations of prospective students to study in the Master of Business Administration Program of Suan Sunandha Rajabhat University, Thailand; and 2. Study factors influencing these prospective students' decision.

\section{Research Methodology}

This research study employed a quantitative research methodology. The study followed the steps below:

1. Developing and testing a study tool

2. Collecting the data from related research, textbooks, documents, and academic articles

3. Conducting a fieldwork study by distributing a questionnaire, both on-line and by the researcher herself

4. Analyzing the collected quantitative data

Population and sample

Population in this study were fourth-year students in Suan Sunandha Rajabhat University, staff members of the university and general people. As for sample, 100 respondents were selected using simple random sampling.

Place and period of time of the study

The study was conducted in Bangkok between October 2017 and July 2018.

Data analysis

Collected data were analyzed with descriptive statistics as follows:

1. General data of the respondents were analyzed with frequency and percentage;

2. Other data were analyzed with means $(\bar{x})$ and standard deviation (S.D.) 


\section{Research Findings}

Based on the data analysis of the study on factors influencing prospective students' decision to study in the Master of Business Administration Program of Suan Sunandha Rajabhat University, the findings are as follows.

In Part 1 which is about the demographic background of the respondents, it was found that most of them were female (66 percent), aged between $25-30$ years (47 percent), were government officers (52 percent).

In part 2 which is about factors influencing their decision to study in the program, the findings are showed in the following tables.

Table 2 Factors Influencing Prospective Students' Decision to Study in the Program

\begin{tabular}{|c|c|c|c|}
\hline Items (Factors) & $\overline{\bar{x}}$ & S.D. & Opinion Level \\
\hline \multicolumn{4}{|l|}{ An Image of the University } \\
\hline 1. Reputation of the university & 4.46 & .500 & Highest \\
\hline $\begin{array}{l}\text { 2. The university's academic works is accepted in the } \\
\text { society and country for its high standard }\end{array}$ & 4.24 & .780 & Highest \\
\hline $\begin{array}{l}3 \text {. The university is certified for its standards of } \\
\text { education }\end{array}$ & 4.68 & .468 & Highest \\
\hline 4. The university is an archetype university of the society & 4.49 & .559 & Highest \\
\hline $\begin{array}{l}5 \text {. The university has modern learning and teaching } \\
\text { activities }\end{array}$ & 4.38 & .599 & Highest \\
\hline Total & 4.45 & .479 & Highest \\
\hline
\end{tabular}

\section{Items (Factors)}

\section{Curriculum and Teaching and Learning Activities}

1. The program has teaching and learning activities both in terms of theory and practicum

2 . Contents of the subjects are modern and consistent with current situation

3. Content of each subject is continuous and linked with other subjects

4 . Contents of the subjects encompass all important topics

5 . Contents of the subjects and learning and teaching activities encourage students to have various ideas

\section{Total \\ Fee of the Program}

1. Fee for the whole program is appropriate

2. Other expenses $\bar{x} \quad$ S.D. Opinion Level

$4.24 \quad 637$ Highest

4.27 .649 Highest

4.22 .595 Highest

4.15 .701 High

$4.30 \quad 674$ Highest $4.23 \quad .544$ Highest

4.44 .591 Highest

4.39 .617 Highest 
3. Educational maintenance expenses

$4.45 \quad 657$ Highest

Total

$4.42 \quad .552$ Highest

\section{Location of the University}

1. Location of the university

$\begin{array}{lll}4.26 & .811 \text { Highest }\end{array}$

2. Convenient transportation

$4.26 \quad .860$ Highest

3. Environment of the university

$4.16 \quad .825$ High

4. Full option of equipment and modern equipment

\section{Total}

4.22 .823 Highest

\section{Promotion}

1. Using electronic media such as internet, website etc.

$4.22 \quad .671$ Highest

to promote the program

2. Using vinyl banners and other media to promote the program

3. Promoting the program among alumni

4.18 .796 High

4. Providing discounts of the fee

\section{Total}

Overall

$4.05 \quad .729$ High

$\begin{array}{lll}4.30 & .717 \text { Highest }\end{array}$

4.52 .688 Highest

$4.26 \quad .603$ Highest

4.32 .397 Highest

According to the table, it can be seen that the above mentioned factors had a very influence on the prospective students with the mean score of 4.32. When considering at each factor, it was found that the most influencing factor was an image of the university $(\bar{x}=4.45)$, followed by program fee $(\bar{x}=4.42)$, promotion activities $(\bar{x}=$ 4.26), curriculum and learning and teaching activities $(\bar{x}=4.23)$, and location of the university $(\bar{x}=4.22)$. The reason behind this result was based on the fact that Suan Sunandha Rajabhat University has been accepted as one of the best universities in Thailand. It has been ranked as the best university in Rajabhat system for many years.

The finding of this study is consistent with the finding from Ms.Uamduang Darat (2550)'s study which revealed that the most influencing factor for a decision to study in the MBA program of administrators in the private universities of Thailand was to gain prestige in the society and reputation of the university. These factors are parts of the credibility of the university.It is also consistent with the study ofKhaiwwan, D. et at. (2003)who studied on the needs to study at the master's degree level of academic support staff of universities in NakhonPathom Province, Thailand. This study found that rate of fee was the most influencing factor for prospective students and they preferred to pay a fee in a form of lump sum payment. The study's finding is also supported by that of Mudla, N., \&Thubhiranrak, T. (2015)which examines relationship between motivations and marketing mix and the decision of grade 12 students studying in schools under a supervision of universities in the Rajabhat system in Bangkok. This study found that these students' decision was different depending on their capability to study, economic status, goal of life, and many other factors. 


\section{References}

Graduate School Suan Sunandha Rajabhat University .(2017). Public Relations Student Handbook Graduate School

Kittisatta Poompeng (2008). The study of decision-making in undergraduate studies at the Faculty of Science. Special Problems Master of Public Administration, Public Administration, College of Public Administration, Burapha University

Ms.Uamduang Darat .2007 . Factors influencing the decision to choose MBA program for executives in private higher education institutions in Thailand. Master's Degree, Rangsit University

Kunpluem, P. (2010). The study of factors affecting undergraduate student decision- making to study Master's degree: Case study of students in the faculty of Business Administration at Sripatum university Chonburi campus. Sripatum Chonburi Journal, 9(2), 35-43.

Mudla, N., \&Thubhiranrak, T. (2015). Motivations for further study and marketing mix related to the decision making tendency of twelfth grade students from the schools affiliated with Rajabhat Universities in Bangkok to continue studying at Rajabhat University. SSRU Graduate studies journal, 8(Special), 372-383

Khaiwwan, D. et at. (2003). The survey of needs for studying in Master's degree program among educational personnel in NakhonPathom. Unpublished independent study. NakhonPathom: Rajabhat Institute NakhonPathom. 